\title{
SISTEM SYARIKAH ABDAN DALAM FIKIH ISLAM DAN CONTOH PENERAPANNYA PADA ERA KONTEMPORER
}

\section{ABDAN SYARIKAH SYSTEM IN ISLAMIC JURISPRUDENCE AND EXAMPLES OF ITS APPLICATION IN THE CONTEMPORARY ERA}

\author{
Rahmat \\ Sekolah Tinggi Ilmu Islam dan Bahasa Arab (STIBA) Makassar \\ rahmatar09@stiba.ac.id \\ Fitriah Ningsih \\ Sekolah Tinggi Ilmu Islam dan Bahasa Arab (STIBA) Makassar \\ fitriahningsih222@gmail.com
}

\begin{tabular}{|c|c|}
\hline Keywords: & ABSTRACT \\
\hline $\begin{array}{l}\text { Economics, Islamic } \\
\text { Jurisprudence, Syarikah Al- } \\
\text { Abdan. }\end{array}$ & $\begin{array}{l}\text { Syarikah al-abdan is a form of muamalah that can be applied today } \\
\text { in improving the welfare of the people. However, in practice today, } \\
\text { it seems that there are problems among Muslims in seeing and } \\
\text { sorting out the practice of syarikah al-abdan which is following the } \\
\text { Shari'a. For this reason, the purpose of this study is to describe the } \\
\text { syarikah al-abdan scheme and its current contemporary } \\
\text { application forms. The research method used is a qualitative } \\
\text { descriptive research approach with library research techniques and } \\
\text { content analysis. The results of this study indicate that syarikah al- } \\
\text { abdan is a form of business cooperation between two or more } \\
\text { people preceded by mutual agreement in determining the results of } \\
\text { the profits and/or wages between them. However, in its } \\
\text { implementation, it is necessary to pay attention to the pillars and } \\
\text { requirements of the syarikah al-abdan, and to consider the views of } \\
\text { the majority of madhhab scholars and the Indonesian Ulama } \\
\text { Council (MUI). In practice, this study describes the form of } \\
\text { syarikah al-abdan in the profession of fisherman and tailor. }\end{array}$ \\
\hline \multirow{2}{*}{$\begin{array}{l}\text { Kata kunci : } \\
\text { Ekonomi, Fikih Islam, Syarikah } \\
\text { Al-Abdan. }\end{array}$} & ABSTRAK \\
\hline & $\begin{array}{l}\text { Syarikah Al-Abdan adalah salah satu bentuk muamalah yang dapat } \\
\text { diterapkan dewasa ini dalam meningkatkan kesejahteraan umat. } \\
\text { Namun, dalam praktiknya di kontemporer saat ini, tampak menuai } \\
\text { problematika di kalangan umat Islam dalam melihat dan memilah } \\
\text { praktek Syarikah Al-Abdan yang sesuai syariat. Untuk itu, tujuan } \\
\text { penelitian ini adalah mendeskripsikan skema Syarikah al-abdan dan } \\
\text { bentuk-bentuk penerapannya di kontemporer saat ini. Metode } \\
\text { penelitian yang digunakan adalah pendekatan penelitian deskriptif } \\
\text { kualitatif dengan teknik penelitian kepustakaan (library research) } \\
\text { dan analisis konten (content analysis). Hasil penelitian } \\
\text { menunjukkan bahwa Syarikah al-abdan adalah suatu bentuk } \\
\text { kerjasama bisnis antara dua orang atau lebih dengan didahului oleh } \\
\text { kesepakatan bersama dalam penetapan hasil dari keuntungan dan } \\
\text { atau upah di antara mereka. Namun, dalam pelaksanaannya perlu } \\
\text { memperhatikan rukun dan syarat Syarikah Al-Abdan, serta } \\
\text { mempertimbangkan pandangan mayoritas ulama Mazhab dan }\end{array}$ \\
\hline
\end{tabular}


Diterima: 20 April 2021; Direvisi: 21 April 2021; Disetujui: 22 April 2021; Tersedia online: 23 April 2021

How to cite: Rahmat dan Fitriah Ningsih, "Sistem Syarikah Abdan dalam Fikih Islam dan Contoh Penerapannya pada Era Kontemporer", BUSTANUL FUQAHA: Jurnal Bidang Hukum Islam 2, No.1. (April 21, 2021): 130-147. doi: https://doi.org/10.36701/bustanul.v2i1.327

\section{PENDAHULUAN}

Islam adalah karunia dan nikmat terbesar yang dianugerahkan kepada umat manusia. Cahayanya menerangi kalbu, sinarnya menghempaskan kejahilan umat, petunjuknya di atas segala petunjuk, keutamaannya tidak lekang dimakan waktu. Islam datang sebagai rahmatan li al- 'alamin untuk menjawab segala permasalahan pada setiap masa dan tempat, sehingga tidak ada satu pun permasalahan kecuali telah ada jawabannya di dalam Al-Qur'an dan sunah Rasulullah saw. Allah Ta'ala berfirman dalam Qs. Al-Naḥl/16:89,

Terjemahnya:

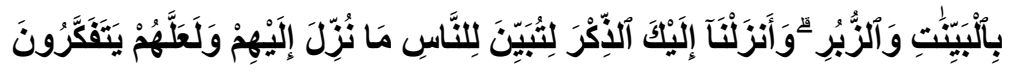

"Dan Kami turunkan kepadamu al-Kitāb (Al-Qur'an) untuk menjelaskan

segala sesuatu dan petunjuk serta rahmat dan kabar gembira bagi orang-

orang yang berserah diri"1.

Syariat yang Allah swt. turunkan kepada Nabi Muhammad saw. mencakup kemaslahatan dunia dan akhirat, segala sesuatu yang sesuai dengan syariat itu adalah kebenaran sebaliknya apa saja yang menyelisihi syariat itu adalah kebatilan. Islam sebagai agama yang telah ditempatkan sebagai suatu pilihan dan sekaligus ajarannya dijadikan pedoman dalam kehidupan umat manusia. Untuk itu, keberadaannya telah memberikan arahan dalam pengembangan peradaban umat manusia.

Manusia adalah makhluk sosial yang membutuhkan interaksi, dengan berinteraksi mereka dapat saling mengambil manfaat. Di dalam ajaran Islam interaksi manusia dengan individu lainnya diatur dalam fikih muamalah. Fikih muamalah secara umum bermakna aturan-aturan Allah yang mengatur manusia sebagai makhluk sosial dalam semua urusan yang bersifat duniawi. Adapun secara khusus fikih muamalah mengatur berbagai akad atau transaksi yang membolehkan manusia saling memiliki harta benda dan saling tukar-menukar manfaat berdasarkan syariat Islam².

Agama Islam menganjurkan umatnya untuk memikirkan urusan-urusan dunianya karena tidak banyak ayat-ayat Al-Qur'an yang mengatur untuk menunjukkan secara

\footnotetext{
${ }^{1}$ Departemen Agama R.I., Alquran Terjemahan (Tangerang Selatan: Kalim, 2011), 278.

${ }^{2}$ Andri Soemitra, Hukum Ekonomi Syariah dan Fikih Muamalah di Lembaga Keuangan dan Bisnis Kontemporer (Cet. I; Jakarta Timur: Prenadamedia Group, 2019), 2.
} 
jelas jenis-jenis muamalah wajib bagi umat Islam. Hal ini dimaksudkan agar umat Islam bisa sebebas-bebasnya melakukan apa saja dalam urusan dunia. Disadari ataupun tidak sesungguhnya Alquran memahami bahwa kehidupan duniawi manusia senantiasa berubah-ubah mengikuti perkembangan zaman, maka jika Alquran mendefinisikan secara rinci jenis dan bentuk perbuatan muamalah barangkali ajaran Islam akan terkubur oleh kemajuan budaya manusia ${ }^{3}$. Adanya kehidupan yang bervariasi ini sesungguhnya mengajarkan umat Islam untuk saling tolong-menolong. Banyak ayat Al-Qur'an dan hadis yang menunjukkan hal ini. Allah berfirman dalam Qs. Al-Māidah/5:2,

Terjemahnya:

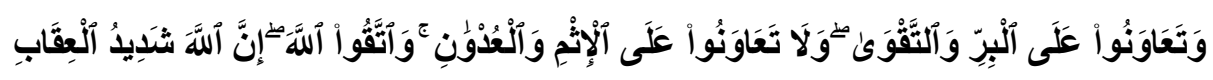

"Dan tolong-menolonglah kamu dalam (mengerjakan) kebajikan dan takwa, dan jangan tolong-menolong dalam berbuat dosa dan pelanggaran. dan bertakwalah kamu kepada Allah, Sesungguhnya Allah Amat berat siksa-Nya."

Salah satu bentuk tolong-menolong dalam hubungan interaksi manusia atau muamalah adalah kerja sama atau perkongsian. Istilah kerja sama atau perkongsian di dalam Islam dikenal dengan syarikah. Menurut Sayyid Sābiq, yang dimaksud dengan syarikah ialah akad antara dua orang yang berserikat pada pokok harta atau modal dan keuntungan. Secara umum syarikah terbagi menjadi dua, yaitu syarikah amlak dan syarikah 'uqud. Syarikah Amlak yaitu persekutuan dua orang atau lebih dalam pemilikan suatu barang tanpa adanya akad. Syarikah amlak terbagi menjadi dua, yaitu Ikhtiyariyyah dan Jabariyyah. Ikhtiyariyyah yaitu apabila dua orang yang dihibahkan atau diwariskan sesuatu lalu mereka berdua menerima, maka barang yang dihibahkan atau diwasiatkan itu menjadi milik mereka berdua. Sedangkan Jabariyyah adalah syarikah yang terjadi tanpa adanya kehendak masing-masing pihak (secara terpaksa) seperti persekutuan ahli waris terhadap warisan tertentu ${ }^{5}$.

Syarikah 'Uqūd ialah syarikah yang terjadi antara dua pihak atau lebih dalam usaha, modal dan keuntungan. Syarikah 'Uqūd terbagi ke dalam beberapa macam, di antaranya: Syarikah Al-'Anān, Ayarikah Al-Mufāwaḍah, Syarikah Al-Abdan dan Syarikah Al-Wujūh. Syarikah Al-Anān adalah dua orang yang saling bersekutu/berkongsi pada harta di mana keduanya berniaga (berbisnis) dengan harta tersebut untuk memperoleh keuntungan bersama. Sedangkan Syarikah Al-Mufāwadah adalah persekutuan di antara dua pihak atau lebih pada suatu pekerjaan di mana posisi dan komposisi yang terlibat di dalamnya adalah sama, baik dalam hal modal,

\footnotetext{
${ }^{3}$ Muhammad, Etika Bisnis Islami (Yogyakarta: Unit Penerbit dan Percetakan Akademi Manajemen Perusahaan YKPN, 2004), 78.

${ }^{4}$ Departemen Agama R.I., Alquran Terjemahan (Tangerang Selatan: Kalim, 2011), 107.

${ }^{5}$ Sayyid Sābiq, Fiqh al-Sunnah, (Cet.III; Beirut: Dār al-Kitāb al-'Arabī, 1397 H/1977 M), 354356.
} 


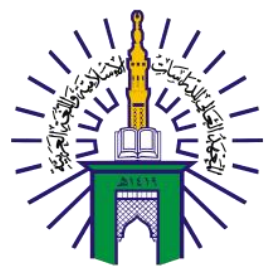

\section{BUSTANUL FUQAHA: \\ JURNAL BIDANG HUKUM ISLAM \\ Vol. 2 No. 1 (2021): Hal. 130-147 \\ EISSN: 2723-6021 \\ Website: https://journal.stiba.ac.id}

kedudukan, agama dan tanggung jawab. Syarikah Al-Abdan adalah persekutuan dua pihak pekerja untuk mengerjakan suatu pekerjaan di mana hasil atau upah dari pekerjaan tersebut dibagi sesuai kesepakatan mereka. Adapun Syarikah Al-Wujūh adalah dua orang atau lebih yang bersekutu tanpa adanya modal dari keduanya dengan mengandalkan reputasi (nama baik) mereka berdua dan kepercayaan para pedagang kepada mereka berdua ${ }^{6}$.

Dari macam-macam syarikah tersebut, salah satu macam syarikah yang menimbulkan perbedaan pendapat di kalangan ulama fikih yaitu syarikah abdān. Terkait dengan syarikah al-abdan, jumhur (kebanyakan) ulama fikih memperbolehkannya sementara di lain pihak Imam al-Syāfi'’̄ melarangnya. Perbedaan pendapat ini berdasarkan pada adanya hadis Rasulullah saw. yang diriwayatkan oleh 'Abdullah bin Mas'ud berkata:

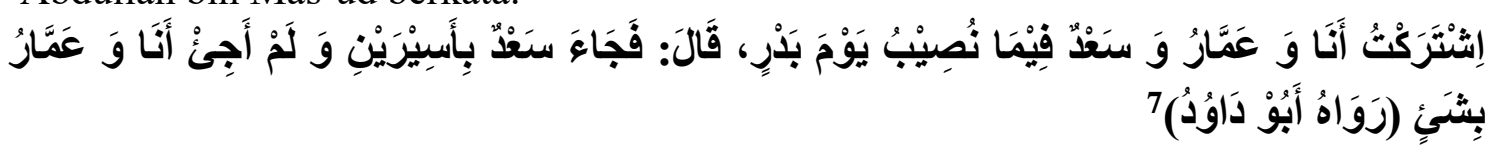

Artinya:

"Aku pernah berkongsi (bersyarikah) dengan 'Ammār dan Sa'ad dalam perolehan bagian perang Badar, lalu $S a$ 'ad datang membawa dua orang tawanan, sedangkan aku dan 'Ammār tidak membawa apa-apa."

Imam Ahmad mengatakan: Nabi saw. lantas membagi dua tawanan itu untuk mereka bertiga (Ibnu Mas'ud, 'Ammār dan Sa'ad). Hal ini menunjukkan bahwa berkongsi atas apa yang dihasilkan oleh badan hukumnya sah (boleh) ${ }^{8}$. Islam tidak menolak setiap kerja sama yang memungkinkan terbentuknya organisasi bisnis yang menguntungkan. Sesungguhnya salah satu tujuan dasar Islam adalah menggunakan sumber dan kekuatan negara dalam memproduksi kekayaan serta untuk mengoordinasikan persediaan tenaga kerja dan modal yang dapat digunakan dalam kepentingan masyarakat. Semua bentuk organisasi bisnis seperti perdagangan, perniagaan, pendidikan, transportasi, pembangunan, dan masih banyak lagi dibentuk kaum muslimin untuk melangsungkan perekonomian saat itu. Semua ini dan ribuan lebih organisasi bisnis dapat dibentuk berdasarkan prinsip-prinsip yang sama untuk pembangunan ekonomi kita dan untuk memenuhi tuntunan zaman modern pada saat ini ${ }^{9}$.

Kerja sama untuk saling memperoleh keuntungan, apabila sesuai dengan etika bisnis dalam Islam, maka hal itu diperbolehkan bahkan dianjurkan. Keterlibatan muslim

\footnotetext{
${ }^{6}$ Sayyid Sābiq, Fiqh al-Sunnah, (Cet.III; Beirut: Dār al-Kitāb al-‘Arabī, 1397 H/1977 M), 355359.

${ }^{7}$ Abū Dāwūd Sulaimān bin al-Asy'aṣ bin Ishāạq bin Basyīr bin Syidād hin Amri al-Azdī alSijistān̄̄, al-Sunan, Juz 5 (Cet. I; t.t: Dār al-Risālah al-Ālamiyah, 2009 M/1430 H), 269.

${ }^{8}$ Șāliḥ bin Fauzān Bin Abdillāh al Fauzān, al Mulakhkhaș al Fiqhī, Juz 2 (Riyāọ : Dār $\quad$ al 'Āṣimah, 1423 H), 133. 1997), 281.

${ }^{9}$ Afzalurrahman, Muhammad Sebagai Seorang Pedagang (Jakarta : Yayasan Swarna Bhuny,
} 


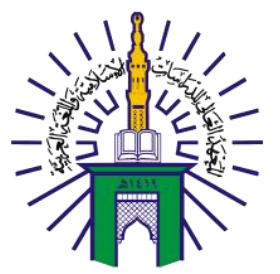

\section{BUSTANUL FUQAHA: \\ JURNAL BIDANG HUKUM ISLAM \\ Vol. 2 No. 1 (2021): Hal. 130-147 \\ EISSN: 2723-6021 \\ Website: https://journal.stiba.ac.id}

di dunia bisnis telah berlangsung selama empat belas abad yang lalu. Namun, muslim dewasa ini menghadapi suatu masalah yang sangat dilematis. Meskipun berpartisipasi aktif dalam dunia bisnis, namun dalam pikiran mereka juga ada semacam ketidakpastian apakah praktik-praktik bisnis mereka benar menurut pandangan Islam. Yang menjadi masalah yaitu bentuk-bentuk baru, institusi, metode atau teknik-teknik bisnis yang sebelumnya belum pernah ada telah menyebabkan keraguan tersebut, sehingga dalam beberapa kasus, mereka tetap mengikuti sistem tersebut dengan perasaan bersalah karena mereka merasa tidak menemukan jalan keluar ${ }^{10}$.

Tidak dapat dipungkiri permasalahan seperti ini muncul dikarenakan ketidaktahuan sebagian besar umat muslim akan sistem perekonomian yang benar di dalam Islam. Namun, yang lebih ironisnya mereka tidak berusaha untuk mempelajari terlebih dahulu sistem perekonomian yang benar dalam Islam dan memilih tenggelam dalam ketidaktahuan mereka. Dewasa ini, kebanyakan umat muslimin lebih mementingkan keuntungan yang akan diperoleh dari transaksi ekonomi yang mereka jalankan tanpa memperhatikan keabsahan transaksi ekonomi tersebut.

Berdasarkan atas uraian latar belakang di atas, maka dapat dirumuskan beberapa substansi masalah yang akan dijadikan acuan dan dikembangkan dalam pembahasan ini, yaitu sistem Syarikah Al-Abdan yang dapat diterapkan pada masa kontemporer. Untuk itu, dalam mengkajinya lebih mendalam maka digunakan metode penelitian dengan pendekatan penelitian deskriptif kualitatif dengan teknik penelitian kepustakaan (library research) dan analisis konten (content analysis).

\section{PEMBAHASAN}

\section{Sistem Syarikah Al-Abdan}

Pengertian Syarikah Al-Abdan

Syarikah Al-Abdan berasal dari dua suku kata, yaitu syarikah dan abdān. Kata

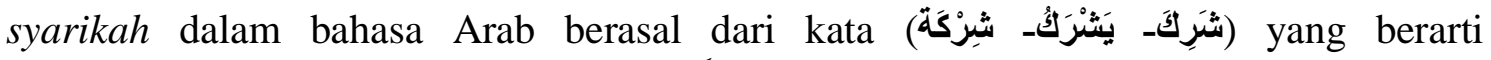
bersekutu ${ }^{11}$. Sedangkan kata abdān (أَبْنانُ) dalam bahasa Arab merupakan jamak dari kata بََْ yang berarti tubuh atau badan ${ }^{12}$. Secara konteks bahasa, Syarikah Al-Abdan berarti bersekutu atau bekerja sama dengan menggunakan tubuh atau anggota badan. Para ulama Islam berbeda pendapat dalam menjelaskan makna Syarikah Al-Abdan secara istilah fikih, sebagai berikut: (1) Menurut Syekh Sayyid Sabiq, Syarikah AlAbdan yaitu dua pihak bersepakat untuk menerima suatu pekerjaan dengan ketentuan upah dari pekerjaan ini dibagi di antara keduanya sesuai dengan kesepakatan ${ }^{13}$; (2)

\footnotetext{
${ }^{10}$ Ahmad Mustaq, Etika Bisnis Dalam Islam (Jakarta : Pustaka al-Kautsar, 2005), 1.

${ }^{11}$ Ahmad Warson Munawwir, Kamus al Munawwir Arab-Indonesia (Cet.XIV; Surabaya: Pustaka Progressif, 1997), 715.

${ }^{12}$ Ahmmad Warson Munawwir, Kamus al Munawwir Arab-Indonesia (Cet.XIV; Surabaya: Pustaka Progressif, 1997), 66.

${ }^{13}$ Sayyid Sābiq, Fiqh al-Sunnah, (Juz 3 Beirut: Dār al-Kitāb al-Arabi, 1977), 356.
} 


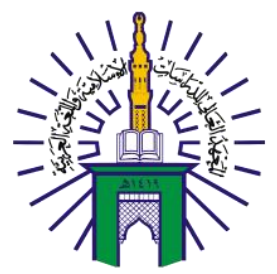

\section{BUSTANUL FUQAHA: \\ JURNAL BIDANG HUKUM ISLAM \\ Vol. 2 No. 1 (2021): Hal. 130-147 \\ EISSN: 2723-6021 \\ Website: https://journal.stiba.ac.id}

Menurut Dr. Wahbah Zuhaili, Syarikah Al-Abdan yaitu persekutuan dua orang yang masing-masing memiliki pekerjaan (seperti penjahit, tukang besi, tukang warna pakaian dan lain sebagainya) dan keuntungan dari pekerjaan keduanya dibagi di antara mereka $^{14}$; (3) Menurut Dr. Shalih Al-Fauzan, Syarikah Al-Abdan ialah patungan yang dilakukan oleh dua orang atau lebih atas apa yang mereka hasilkan dengan badan mereka ${ }^{15}$; (4) Menurut ulama penyusun Kitab Fiqh al-Muyassar, Syarikah Al-Abdan yaitu dua orang yang berkongsi pada pekerjaan mubah dan dilakukan dengan tenaga badan mereka berdua, seperti: mencari rumput, berburu, mengumpulkan barang tambang, mencari kayu bakar, atau dua orang berkongsi dalam menerima pekerjaan yang mereka berdua pikul, seperti: menenun, menjahit dan yang semisalnya ${ }^{16}$.

\section{Rukun dan Syarat Syarikah Al-Abdan}

Pada dasarnya rukun dalam Syarikah Al-Abdan sama dengan rukun syarikah secara umum, perbedaannya hanya terletak pada obyek transaksi syarikah (ma'qūd 'alaihi). Pada syarikah secara umum, obyek transaksi yaitu harta (modal), sedangkan obyek transaksi pada syarikah al-abdan adalah amal (pekerjaan). Menurut Mazhab Hanafi, rukun syarikah 'uqūd ada dua, yaitu ijab dan kabul, maka jika salah satu pihak berkata kepada mitranya, "Aku berkongsi dengan kamu dalam hal ini atau ini", kemudian pihak kedua menjawab, "Aku setuju", berarti telah sah terjadi syarikah ${ }^{17}$. Menurut jumhur ulama, yaitu Mazhab Maliki, Syafi'i dan Hambali, rukun syarikah ada tiga, yaitu 'āqidān atau dua orang yang bertransaksi, ma'qūd 'alaihi yaitu barang yang menjadi obyek transaksi dan sighah yaitu ijab dan kabul ${ }^{18}$.

Buku Fikih Ekonomi Syariah menjelaskan ketiga rukun Syarikah Al-Abdan ini, yaitu $^{19}$ : (1) Sighah, Sighah yaitu ungkapan yang keluar dari masing-masing dua pihak yang bertransaksi yang menunjukkan kehendak untuk melaksanakannya. Sighah terdiri dari ijab dan kabul yang sah dengan semua hal yang menunjukkan maksud syarikah alabdan, baik berupa perbuatan maupun ucapan; (2) Dua orang yang melakukan transaksi ('äqidān), 'Āqidain adalah dua pihak yang melakukan transaksi. Syarikah AlAbdan tidak sah kecuali dengan adanya kedua pihak ini. Disyaratkan bagi keduanya kelayakan melakukan usaha (balig, berakal, pandai dan memiliki keahlian); (3) Obyek

\footnotetext{
${ }^{14}$ Wahbah bin Musṭafā al-Zuhailī, al-Fiqh al-Islāmīy wa Adillatuhu (Juz 5, Suriah: Dār al-Fikr, t.th.), 3887.

${ }^{15}$ Șālih bin Fauzān bin Abdillāh al Fauzān, al Mulakhkhaṣ al Fiqhī (Juz 2, Riyāḍ : Dār al 'Āșimah, $1423 \mathrm{H}), 133$.

${ }^{16}$ Tim Ulama Fikih, al-Fiqh al-Muyassar Fī Ḋau al Kitāb Wa Sunnah (t.t. Mujamma' al Malik Fahd Lițibā'ati al Mușhaf al Syarīf, 1424 H), 241.

${ }^{17}$ Fakhruddin al Zayla'̄̄ al Hanafî, Tabyīn al Haqāiq, (Juz 3, Cairo: Al Kubrā al Amīriyah, 1313 H), 313.

${ }^{18}$ Wahbah bin Musțafā al-Zuhailī, al-Fiqh al-Islāmīy wa Adillatuhu, Juz 5 (Cet. XII; Suriah: Dār al-Fikr, t.th), 3879.

${ }^{19}$ Mardani, Fiqh Ekonomi Syariah: Fiqh Muamalah, (Jakarta : Kencana, 2002), 226.
} 
yang ditransaksikan (ma'qūd 'alaih), adapun obyek syarikah al-abdan yaitu modal pokok berupa usaha dan keahlian/keterampilan dalam pekerjaan. Modal pokok syarikah al-abdan harus ada. Hal ini dikarenakan tanpa adanya keahlian atau keterampilan maka tidak bisa dikatakan syarikah al-abdan.

Syarat keabsahan Syarikah Al-Abdan juga mengikut kepada syarat keabsahan Syarikah Al- 'Uqud secara umum, yaitu' ${ }^{20}$ : (1) Bisa diwakilkan, pekerjaan yang menjadi objek akad syarikah harus bisa diwakilkan, karena di antara ketentuan syarikah adalah adanya persekutuan dalam keuntungan yang dihasilkan dari perdagangan. Keuntungan perdagangan tidak akan menjadi hak milik bersama, kecuali jika masing-masing pihak bersedia menjadi wakil bagi mitranya dalam mengelola sebagian harta syarikah, dan bekerja untuk dirinya sendiri atas sebagian atas sebagian harta syarikah yang lain. Atas dasar hal itu, masing-masing pihak yang tergabung dalam syarikah harus memberi izin kepada mitranya untuk mempergunakan harta syarikah, baik untuk membeli barang, menjual atau menerima pekerjaan. Oleh karena wakil adalah orang yang bertindak atas izin dari pihak lain. Dan mengingat syarikah dengan berbagai jenisnya mengandung makna pemberian kuasa, atau perwakilan dari masing-masing pihak terhadap rekannya, maka disyaratkan agar akad yang ada dalam syarikah tersebut bisa diwakilkan, dan masing-masing pihak bersedia menjadi wakil dan mau mewakilkan; (2) Jumlah keuntungan yang dihasilkan hendaknya jelas, bagian keuntungan tiap-tiap pihak harus jelas secara persentatif, seperti seperlima, sepertiga, atau sepuluh persen. Jika keuntungannya tidak jelas, maka akad syarikah menjadi tidak sah, karena keuntungan itulah yang menjadi objek transaksi, dan tidak jelasnya objek transaksi akan merusak transaksi; (3) Bagian keuntungan yang diberikan hendaknya tidak berbeda dan tidak tertentu, jika keduanya menentukan keuntungan tertentu untuk salah satu sekutu, seperti sepuluh atau seratus, maka syarikah tersebut batal atau tidak sah. Pasalnya, transaksi syarikah mengharuskan persekutuan dalam keuntungan, karena bisa saja keuntungan itu tidak tercapai kecuali sesuai dengan keuntungan salah satu mitra. Oleh karena itu, penentuan bagian keuntungan dalam jumlah tertentu adalah bertentangan dengan konsekuensi akad syarikah.

Adapun beberapa ketentuan tambahan mengenai syarikah yang berpedoman pada fatwa DSN MUI No:08/DSN-MUI/IV/2000 tentang Pembiayaan Musyarakah, antara lain: (1) Pernyataan ijab dan kabul harus dinyatakan oleh para pihak untuk menunjukkan kehendak mereka dalam mengadakan kontrak (akad), dengan memperhatikan hal-hal berikut: (a) Penawaran dan penerimaan harus secara eksplisit menunjukkan tujuan kontrak (akad); (b) Penerimaan dan penawaran dilakukan pada saat kontrak; (c) Akad dituangkan secara tertulis, melalui korespondensi atau dengan menggunakan cara-cara komunikasi modern; (2) Pihak-pihak yang berkontrak harus

${ }^{20}$ Wahbah bin Musțafā al-Zuhailī, al-Fiqh al-Islāmīy wa Adillatuhu, (Juz 5, Cet. XII; Suriah: Dār al-Fikr, t.th.), 3879. 


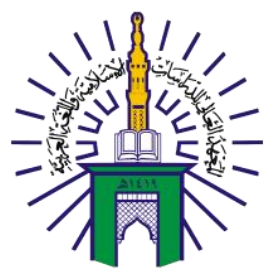

\section{BUSTANUL FUQAHA: \\ JURNAL BIDANG HUKUM ISLAM \\ Vol. 2 No. 1 (2021): Hal. 130-147 \\ EISSN: 2723-6021 \\ Website: https://journal.stiba.ac.id}

cakap hukum, dan memperhatikan hal-hal berikut: (a) Kompeten dalam memberikan atau diberikan kekuasaan perwakilan; (b) Setiap mitra harus menyediakan dana dan pekerjaan, dan setiap mitra melaksanakan kerja sebagai wakil; (c) Setiap mitra memiliki hak untuk mengatur aset musyarakah dalam proses bisnis normal; (d) Setiap mitra memberi wewenang kepada mitra yang lain untuk mengelola aset dan masing-masing dianggap telah diberi wewenang untuk melakukan aktivitas musyarakah dengan memperhatikan kepentingan mitranya, tanpa melakukan kelalaian dan kesalahan yang disengaja; (e) Seorang mitra tidak diizinkan untuk mencairkan atau menginvestasikan dana untuk kepentingannya sendiri; (3) Obyek akad (modal, kerja, keuntungan dan kerugian): (a) Modal, (i) Modal yang diberikan harus uang tunai, emas, perak atau yang nilainya sama. Modal dapat terdiri dari aset perdagangan, seperti barang-barang, properti dan sebagainya. Jika modal berbentuk aset, harus terlebih dahulu dinilai dengan tunai dan disepakati oleh para mitra; (ii) Para pihak tidak boleh meminjam, meminjamkan, menyumbangkan atau menghadiahkan modal musyarakah kepada pihak lain, kecuali atas dasar kesepakatan; (iii) Pada prinsipnya, dalam pembiayaan musyarakah tidak ada jaminan, namun untuk menghindari terjadinya penyimpangan, LKS dapat meminta jaminan; (b) Kerja, (i) Partisipasi para mitra dalam pekerjaan merupakan dasar pelaksanaan musyarakah; akan tetapi, kesamaan porsi kerja bukanlah merupakan syarat. Seorang mitra boleh melaksanakan kerja lebih banyak dari yang lainnya, dan dalam hal ini ia boleh menuntut bagian keuntungan tambahan bagi dirinya; (ii) Setiap mitra melaksanakan kerja dalam musyarakah atas nama pribadi dan wakil dari mitranya. Kedudukan masing-masing dalam organisasi kerja harus dijelaskan dam kontrak; (c) Keuntungan, (i) Keuntungan harus dikuantifikasi dengan jelas untuk menghindarkan perbedaan dan sengketa pada waktu alokasi keuntungan dan penghentian musyarakah; (ii) Setiap keuntungan mitra harus dibagikan secara proporsional atas dasar seluruh keuntungan dan tidak ada jumlah yang ditentukan di awal yang ditetapkan bagi seorang mitra; (iii) Seorang mitra boleh mengusulkan bahwa jika keuntungan melebihi jumlah tertentu, kelebihan atau persentase itu diberikan kepadanya; (iv) Sistem pembagian keuntungan harus dibagi di antara para mitra secara proporsional menurut saham masing-masing dalam modal; (d) Kerugian, kerugian harus dibagi di antara para mitra secara proporsional menurut saham masing-masing dalam modal, (i) Biaya Operasional dan Persengketaan, di mana, pertama, biaya operasional dibebankan pada modal bersama, dan kedua, jika salah satu pihak tidak menunaikan kewajibannya atau jika terjadi perselisihan di antara para pihak, maka penyelesaiannya dilakukan melalui Badan Arbitrasi Syariah setelah tidak tercapai kesepakatan melalui musyawarah.

\section{Hal-hal yang Membatalkan Syarikah Al-Abdan}




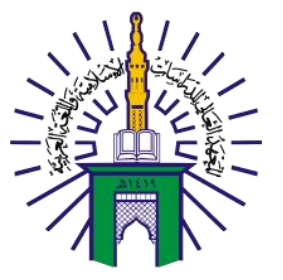

\section{BUSTANUL FUQAHA: \\ JURNAL BIDANG HUKUM ISLAM \\ Vol. 2 No. 1 (2021): Hal. 130-147 \\ EISSN: 2723-6021 \\ Website: https://journal.stiba.ac.id}

Pada dasarnya hal-hal yang membatalkan Syarikah Al-Abdan sama dengan halhal yang membatalkan akad Syarikah secara umum, yaitu ${ }^{21}$ : (1) Salah seorang syarik (orang yang ber-syarikah) membatalkan syarikah. Syarikah adalah akad yang bersifat tidak mengikat menurut mayoritas ulama, maka akad ini memungkinkan untuk dibatalkan; (2) Kematian salah seorang syarik. Jika salah seorang syarik meninggal, maka syarikah menjadi batal karena batalnya kepemilikan dan hilangnya kemampuan dalam membelanjakan harta karena kematian, baik syarik lainnya mengetahui kematiannya maupun tidak. Selain itu, karena setiap syarik adalah wakil dari syarik lainnya, dan dengan meninggalnya muwakkil (orang yang mewakilkan) maka wakīl (orang yang diwakili) tersebut mengetahui kematiannya atau tidak. Hal itu karena kematian adalah pemberhentian secara hukum; (3) Salah seorang syarik murtad atau masuk ke negeri musuh, karena hal ini kedudukannya sama dengan kematian; (4) Salah seorang syarik gila secara permanen (bukan temporal), karena dengan demikian wakil telah keluar dari wakalah, di mana syarikah mencakup akad wakalah.

\section{Perbedaan Pandangan Ulama Islam tentang Hukum Syarikah Al-Abdan Pandangan Mazhab Syafi'i}

Menurut Mazhab Syafi'i, Syarikah Al-Abdan adalah kerjasama yang dilakukan oleh dua orang makelar, pengangkut barang atau dua orang yang ahli atas pekerjaan yang akan mereka kerjakan baik dengan porsi yang sama atau tidak. Perjanjian ini menjadi bentuk syarikah yang tidak sah, baik pekerjaan keduanya adalah sama, seperti tukang kayu dan tukang kayu, maupun pekerjaan keduanya berbeda, seperti penjahit dan tukang kayu. Alasannya, yaitu karena tiap-tiap orang pasti memiliki keistimewaan tersendiri bila dibandingkan dengan yang lainnya, baik dari segi fisik maupun kemampuan yang dimiliki ${ }^{22}$. Selain itu, syarikah hanya boleh dilakukan dengan harta bukan dengan pekerjaan, karena pekerjaan tidak bisa diukur, sehingga menimbulkan ketidakjelasan. Pasalnya, salah satu pihak tidak tahu apakah mitranya mendapatkan keuntungan atau tidak, dan bisa saja salah satu pihak mengerjakan seluruh pekerjaan, sementara mitranya tidak melakukan apa-apa. Oleh karena itu, akan terjadi penipuan jika kedua orang yang menjalin kerja sama tersebut membagi keuntungan kerja ${ }^{23}$.

\section{Pandangan Mayoritas Ulama Mazhab}

Menurut Mazhab Hanafi, Syarikah Al-Abdan hukumnya boleh. Syarikah ini juga biasa disebut Syarikah Taqabbul dan Syarikah Sina'i. Syarikah Taqabbul adalah

21، Alāuddīn Abū Bakr bin Mas'ūd bin Aḥmad al Kāsānī al Hanafì, Badāi'u al Sanāi '̄̄ Fī Tart̄̄b al Syarāi'i (Cet.II; Juz 6, Dār al Kutub al 'Ilmiyah, 1986), 78.

${ }^{22}$ Abū Zakariyyā Muhyiddīn Yahya BinSyaraf al-Nawawī, Raw ḍh al-Ṭālibīn Wa 'Umdah al Muftīn, Juz 4 (Cet. III; Beirut: al Maktab al Islāmī, 1412 H/1991 M), 279.

${ }^{23}$ Wahbah bin Musțafā al-Zuhailī, al-Fiqh al-Islāmīy wa Adillatuhu (Juz 5 Cet. XII; Suriah: Dār al-Fikr, t.th..), 3888-3889. 


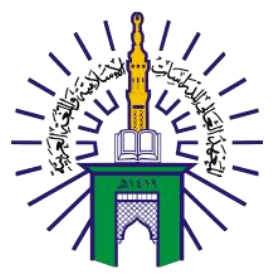

\section{BUSTANUL FUQAHA: \\ JURNAL BIDANG HUKUM ISLAM \\ Vol. 2 No. 1 (2021): Hal. 130-147 \\ EISSN: 2723-6021 \\ Website: https://journal.stiba.ac.id}

dua orang produsen (ahli) yang bekerja sama dalam menerima pekerjaan, seperti tukang jahit dan tukang daging. Syarikah Taqabbul disebut juga syarikah al-abdan karena mereka berdua bekerja dengan tubuh mereka, sedangkan disebut sebagai syarikah sina'i karena modal kerja dihasilkan oleh mereka sendiri ${ }^{24}$. Menurut Mazhab Maliki, syarikah al-abdan hukumnya boleh, jika dilakukan dalam pekerjaan dan tempat yang sama. Seperti syarikah antara dua orang penjahit, tukang daging, pandai besi atau tukang roti yang bekerja pada tempat yang sama ${ }^{25}$. Menurut Mazhab Hambali, syarikah al-abdan adalah dua orang atau lebih bermitra dalam pekerjaan, seperti para tukang yang bermitra untuk bekerja di tempat kerja mereka. Berapa pun rezeki yang diberikan Allah Ta'ala kepada mereka, maka rezeki tersebut dibagi di antara mereka. Syarikah al-abdan hukumnya sah (boleh) ${ }^{26}$. Mas'ud:

Dalil keabsahan syarikah ini, yaitu hadis yang diriwayatkan oleh Abdullah bin

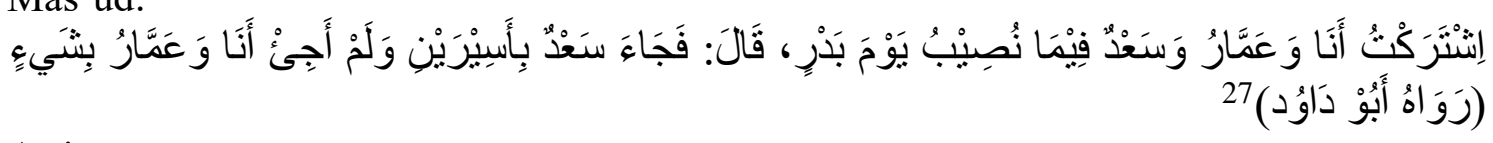

Artinya:

"Aku pernah berkongsi (bersyarikat) dengan 'Ammār dan Sa'ad dalam perolehan bagian perang Badar, lalu Sa'ad datang membawa dua orang tawanan, sedangkan aku dan 'Ammār tidak membawa apa-apa." (HR. Abu Daud).

Menurut Imam Ahmad bin Hanbal, Nabi saw. kemudian membagi dua orang tawanan itu untuk mereka bertiga (Ibnu Mas'ud, 'Ammār dan Sa'ad). Hal ini menunjukkan bahwa berkongsi atas apa yang dihasilkan oleh badan hukumnya sah (boleh) ${ }^{28}$. Menurut Imam Ahmad lagi, keduanya bermitra dalam memiliki rampasan perang pada korban yang diperoleh oleh keduanya, karena pembunuh memiliki sendiri rampasan tersebut, tanpa melibatkan para ganim (penerima rampasan perang) yang lain. Menurut Imam Malik bin Anas ra., alasan lain tentang kebolehan syarikah jenis ini, yaitu hak bersama yang diperoleh dua orang dari harta ganimah (rampasan perang), karena mereka bekerja sama di dalam medan jihad, demikian pula halnya dengan mudarabah hanya terjadi karena adanya pekerjaan bersama ${ }^{29}$.

Mayoritas ulama ini hanya berbeda pendapat mengenai jenis pekerjaan yang dibolehkan didalamnya terjadi transaksi syarikah al-abdan. Menurut Mazhab Hanafi,

${ }^{24}$ Muhammad bin Aḥmad bin Abī Sahli Syamsu al-Aimmah al-Sarakhsī, Al- Mabsut (Juz 11, Beirut: Dār al-Ma'rifah, 1993), 151-152.

${ }^{25}$ Mālik bin Anas bin Mālik bin 'Āmir al Aṣbahī al Madan̄̄, Al Mudawwanah, Juz 3 (Cet. I; t.t: Dār al Kutub al 'Ilmiyah, 1415 H/1994 M), 595.

${ }^{26}$ Abū Muhammad Muwaffaquddin Abdullah bin Aḥmad bin Muhammad bin Qudāmah al Ḥanbalī al Maqdisī, al Mugnī (Juz 5, Maktabah al Qāhirah, 1968), 4.

${ }^{27}$ Abū Dāwūd Sulaimān bin al-Asy'aṣ bin Isḥāq bin Basyīr bin Syidād bin Amri al-Azdī alSijistānī, al-Sunan (Juz 5, Cet. I; Dār al-Risālah al-Ālamiyah, 2009), 269.

${ }^{28}$ Ṣāliḥ bin Fauzān bin Abdillāh al Fauzān, al Mulakhkhaṣ al Fiqhī, (Juz 2, Riyāẹ : Dār al 'Āṣimah, $1423 \mathrm{H}), 133$.

${ }^{29}$ Abū al Walīd Muhammad bin Aḥmad bin Muhammad bin Aḥmad bin Rusyd al Qurṭubī, Bidāyah al Mujtahid wa Nihāyah al Muqtașid, (Juz 4, Cairo: Dār al Hadīṣ, 2004), 38. 
syarikah al-abdan dalam pertukangan hukumnya sah, namun syarikah atas benda-benda mubah (boleh diambil), hukumnya tidak sah, seperti mencari rumput dan merampas harta musuh, karena tujuan dari syarikah adalah perwakilan, sedangkan perwakilan dalam hal-hal tersebut hukumnya tidak sah, maka orang yang mengambilnya itulah yang memilikinya. Berbeda dengan Mazhab Hambali yang berpendapat bahwa perwakilan dalam benda-benda yang mubah itu sah, karena seseorang boleh menyuruh orang lain untuk memperolehnya dengan upah. Begitu pula, menyuruh orang lain tanpa kompensasi itu juga sah apabila salah seorang dari keduanya melakukannya dengan sukarela, sama seperti perwakilan dalam menjualkan hartanya ${ }^{30}$.

Menurut Mazhab Hambali, apabila mereka bermitra dalam melakukan pekerjaan-pekerjaan yang mubah, seperti pertukangan, mengambil buah-buahan dari pegunungan, penambangan serta pencurian di dārul harbi (negeri yang wajib diperangi), maka hukumnya boleh. Sedangkan Imam Ahmad tidak menerima pendapat ini. Menurut Mazhab Maliki, dan Hambali, syarikah al-abdan sah adanya, apabila ada kesamaan pekerjaan, adapun ketika pekerjaannya berbeda-beda maka tidak sah. Imam Mālik juga mengharuskan adanya kesamaan tempat pekerjaan oleh kedua pihak ${ }^{31}$. Sedangkan ulama Hanābilah hanya mensyaratkan adanya kesamaan pekerjaan meskipun kedua pekerjaan itu berada di tempat yang berbeda. Dalil yang menjadi landasan mereka adalah bahwasanya tujuan syarikah adalah pekerjaan yang diterima masingmasing pihak itu wajib baginya dan wajib bagi temannya, dan masing-masing pihak dituntut untuk mengerjakan pekerjaan tersebut.

Apabila salah seorang mitra menerima suatu pekerjaan, padahal keahlian keduanya berbeda di mana yang lain tidak bisa mengerjakannya, maka bagaimana mungkin dia wajib mengerjakannya?, atau bagaimana mungkin dia dituntut melakukan sesuatu yang tidak mampu dikerjakannya ${ }^{32}$. Imam Mālik juga menambahkan bahwasanya adanya perbedaan pekerjaan yang dapat menyebabkan adanya tambahan penipuan $^{33}$. Sedangkan ulama Hanafiyah berpendapat bahwa syarikah tersebut sah walaupun dalam pekerjaan yang berbeda-beda. Alasan mereka karena kedua pihak bermitra dalam megupayakan sesuatu yang mubah, sehingga hukumnya sah, seperti seandainya pekerjaan yang dilakukan itu sama. Juga karena dalam melakukan pekerjaan yang disepakati itu, terkadang salah satu pihak lebih pandai dari pada yang lain, dan

${ }^{30} \mathrm{Abū}$ Muhammad Muwaffaquddin Abdullah bin Aḥmad bin Muhammad bin Qudāmah

Hanbalī al Maqdisī, al Mugnī (Juz 5, Maktabah al Qāhirah, 1968), 4-5.

${ }^{31}$ Mālik bin Anas bin Mālik bin 'Āmir al Aṣbahī al Madan̄̄, Al Mudawwanah (Juz 3, Cet. I; Dār al Kutub al 'Ilmiyah, 1994), 595.

${ }^{32}$ Abū Muhammad Muwaffaquddin Abdullah bin Ahmad bin Muhammad bin Qudāmah al Hanbalī al Maqdisī, al Mugnī (Juz 5, Maktabah al Qāhirah, 1968), 5-6.

${ }^{33}$ Abū al Walīd Muhammad bin Aḥmad bin Muhammad bin Aḥmad bin Rusyd al Qurțubī, Bidāyah al Mujtahid wa Nihāyah al Muqtașid (Juz 4, Cairo: Dār al Had̄̄ṣ, 2004), 3-8 


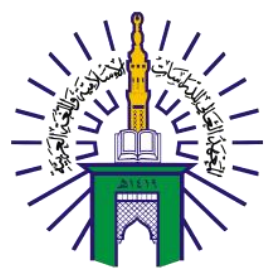

\section{BUSTANUL FUQAHA: \\ JURNAL BIDANG HUKUM ISLAM \\ Vol. 2 No. 1 (2021): Hal. 130-147 \\ EISSN: 2723-6021 \\ Website: https://journal.stiba.ac.id}

barangkali salah satunya menerima apa yang tidak mungkin dilakukan mitranya, namun hal itu tidak menghalangi keabsahannya. Demikian pula ketika pekerjaannya berbeda ${ }^{34}$.

Dari beberapa pemaparan di atas, dapat disimpulkan bahwa syarikah al-abdan menurut ulama Hanafiyah, Mālikiyah, dan Ḥanābilah adalah boleh (sah), karena tujuan dari syarikah ini adalah untuk mendapatkan keuntungan, sementara hal itu bisa dilakukan dengan mewakilkan. Masyarakat juga telah mempraktekkan syarikah jenis ini. Selain itu, karena sebuah syarikah dapat dilakukan dengan modal harta atau dengan modal pekerjaan, sebagaimana dalam muḍarabah, maka di dalam syarikah ini, modal yang digunakan adalah pekerjaan ${ }^{35}$. Alasan keabsahan syarikah al-abdan juga dapat diperkuat oleh kaidah fikih, yang berbunyi:

Artinya:

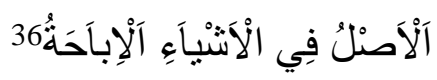

"Hukum asal atas segala sesuatu adalah mubah".

Maksud dari kaidah ini, yaitu bahwa segala sesuatu jenis muamalah yang tidak ada penjelasannya dalam nas syariat tentang halal dan haramnya, maka hukum asalnya adalah halal. Dengan berlandaskan dengan kaidah ini, dapat ditarik suatu kesimpulan bahwasanya hukum asal setiap akad/transaksi ekonomi adalah boleh, kecuali yang diharamkan dalam Al-Qur'an maupun sunah. Selain itu, mengenai adanya ketidakjelasan dalam akad syarikah al-abdan, hal tersebut dapat dicegah dan dihilangkan dengan cara membuat dan menetapkan ketentuan-ketentuan yang jelas sebelum memulai pelaksanaan akad syarikah al-abdan. Penerapan nilai moral syariat dalam setiap transaksi ekonomi, juga dapat mengatasi hal tersebut. Syarikah al-abdan juga menjadi bagian yang sangat penting bagi kehidupan manusia, dan mampu memberikan andil dalam perekonomian masyarakat saat ini. Syarikah al-abdan dapat menjadi salah satu solusi untuk meningkatkan kesejahteraan ekonomi, karena memberi alternatif pilihan buat melakukan kerja sama dan persekutuan usaha.

\section{Contoh Penerapan Syarikah Al-Abdan Pada Masa Kini Penerapan Syarikah Al-Abdan pada Profesi Nelayan di Indonesia}

Kondisi Nelayan di Indonesia ${ }^{37}$, nelayan adalah suatu kelompok masyarakat yang kehidupannya tergantung langsung pada hasil laut, baik dengan cara melakukan penangkapan atau budidaya. Sebagian besar wilayah Indonesia adalah terdiri dari lautan dan memiliki potensi kelautan cukup besar, dengan potensi yang dimiliki tersebut

\footnotetext{
${ }^{34}$ Abū Muhammad Muwaffaquddin Abdullah bin Aḥmad bin Muhammad bin Qudāmah al Hanbalī al Maqdisī, al Mugnī, (Juz 5, Maktabah al Qāhirah, 1968), 6.

${ }^{35}$ Wahbah bin Musțafā al-Zuhailī, al-Fiqh al-Islāmīy wa Adillatuhu, (Juz 5, Cet. XII; Suriah: Dār al-Fikr, t.th.), 3887-3888.

${ }^{36}$ Muslim bin Muhammad bin Mājid al Dawsirī, al Mumti' F̄̄ al Qawā'id al Fiqhiyah (Cet. I; Riyāụ: Dār Zidn̄̄, 1428 H/2007 M), 141.

${ }^{37}$ Henry J.D. Tamboto dan Allen A.Ch. Manongko, Model Pengentasan Kemiskinan Masyarakat Pesisir Berbasis Literasi Ekonomi dan Modal Sosial (Cet. I; Malang: CV. Seribu Bintang, 2019), 88-89.
} 


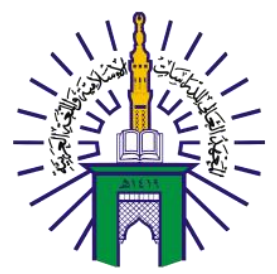

\section{BUSTANUL FUQAHA: \\ JURNAL BIDANG HUKUM ISLAM \\ Vol. 2 No. 1 (2021): Hal. 130-147 \\ EISSN: 2723-6021 \\ Website: https://journal.stiba.ac.id}

seharusnya dapat menyejahterakan kehidupan masyarakat nelayan yang menggantungkan hidup pada potensi kelautan (maritim) tersebut. Namun, kenyataannya, kehidupan masyarakat nelayan senantiasa dilanda kemiskinan, bahkan kehidupan nelayan sering diidentikkan dengan kemiskinan. Tingkat kesejahteraan para pelaku perikanan (nelayan) pada saat ini masih di bawah sektor-sektor lain, termasuk sektor pertanian agraris. Nelayan (khususnya nelayan buruh dan nelayan tradisional) merupakan kelompok masyarakat yang dapat digolongkan sebagai lapisan sosial yang paling miskin di antara kelompok sosial masyarakat lain di sektor pertanian.

Banyak faktor yang menyebabkan kemiskinan nelayan baik secara alamiah, struktural, maupun kultural, di antaranya: (1) Faktor alamiah yang menyebabkan kemiskinan nelayan, yaitu: (a) Gelombang laut yang tinggi; (b) Terjadinya angin kencang dan badai; (c) Rusaknya alam menyebabkan hasil tangkapan semakin sedikit; (2) Faktor struktural yang menyebabkan kemiskinan nelayan, yaitu: (a) Kemampuan modal yang lemah; (b) Manajemen usaha yang rendah; (c) Kelembagaan yang lemah; (d) Nelayan sering berada di bawah cengkraman tengkulak; (e) Keterbatasan teknologi; dan (3) Faktor kultural yang menyebabkan kemiskinan nelayan yaitu adanya ketergantungan terhadap sumber daya alam laut yang melimpah mengakibatkan terjadinya kepasrahan yang mengakibatkan tidak adanya peningkatan kualitas sumber daya manusia.

Seiring dengan berjalannya waktu, kesadaran umat Islam akan pentingnya kembali pada pangkuan agama semakin terasa kuat dan membulat. Sejarah perjalanan umat Islam di Indonesia adalah salah satu buktinya. Seruan untuk menjadikan syariat Islam sebagai asas kehidupan dalam segala aspeknya terus bergemuruh dan menguat hari ini. Tidak heran bila saat ini segala yang berembel-embel Islam atau syariat telah dinanti bahkan laku dijual ke masyarakat. Dimulai dari partai Islam, sekolah Islam, rumah sakit Islam, perusahaan Islam, dan sebagainya. Di antara sektor yang menggeliat dengan kuat ialah sektor perekonomian dan/atau keuangan. Geliat di sektor ini kemudian memunculkan fenomena ramainya bentuk-bentuk sistem dan model interaksi ekonomi dan keuangan, seperti perbankan syariah, asuransi syariah, pegadaian syariah dan lain sebagainya. Dalam tataran teknis, tak asing lagi bagi kita berbagai istilah yang biasa digunakan oleh para ulama ahli fikih dahulu, seperti mudāarabah, ijārah, syarikah, riba, istișnā'dan lain sebagainya ${ }^{38}$.

Manusia sebagai makhluk sosial tidak mampu memenuhi kebutuhan hidupnya tanpa pertolongan orang lain. Salah satu bentuk manusia saling ketergantungan dan saling tolong menolong dalam memenuhi kebutuhan hidupnya adalah dengan melakukan kerja sama dalam mengelola harta yang mereka miliki untuk mendapatkan hasil yang kemudian hasil tersebut mereka bagi sesuai dengan kesepakatan, bentuk kerja

${ }^{38}$ Iskandar, A., \& Aqbar, K, "Reposisi Praktik Ekonomi Islam: Studi Kritis Praktik Ekonomi Islam di Indonesia," NUKHBATUL'ULUM: Jurnal Bidang Kajian Islam 5, no. 1 (2019) : 39-53. 


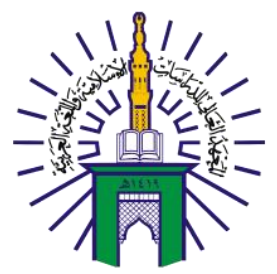

\section{BUSTANUL FUQAHA: \\ JURNAL BIDANG HUKUM ISLAM \\ Vol. 2 No. 1 (2021): Hal. 130-147 \\ EISSN: 2723-6021 \\ Website: https://journal.stiba.ac.id}

sama ini dikenal dengan istilah syarikah. Jadi, syarikah sudah dilakukan oleh manusia sejak mereka hidup dan berusaha memenuhi kebutuhan hidupnya. Pada waktu Islam datang dan risalahnya disampaikan oleh Rasulullah saw. terdapat beberapa aturan (rukun dan syarat) dalam melakukan kerja sama supaya kerja sama tersebut sah menurut syariat Islam.

Syarikah merupakan praktik muamalah masa jahiliah yang diadopsi ke dalam Islam. Dalam fikih Islam, hukum asal syarikah adalah mubah (boleh). Landasan syariat kebolehan syarikah terdapat dalam Al-Qur'an, sunah dan ijmak ulama. Kebolehan syarikah dapat dikembangkan ke dalam berbagai bentuk berdasarkan ijtihad sebagaimana dicontohkan oleh para fukaha. Setelah merujuk pada nas-nas syara', pendapat para fukaha dapat dijadikan referensi untuk pengembangan konsep syarikah dan implementasinya dalam konteks modern ${ }^{39}$. Model syarikah merupakan sebuah konsep yang secara tepat dapat memecahkan permasalahan permodalan. Satu sisi, prinsip Islam menyatakan bahwa segala sesuatu yang dimanfaatkan oleh orang lain berhak memperoleh kompensasi yang saling menguntungkan, baik terhadap barang modal, tenaga atau barang sewa. Di sisi lain, Islam menolak dengan tegas kompensasi atas barang modal berupa bunga. Para ahli ekonomi Islam mendukung pentingnya peranan syarikah dalam pertumbuhan ekonomi masyarakat. Kemandekan ekonomi sering terjadi karena pemilik modal tidak mampu mengelola modalnya sendiri atau sebaliknya mempunyai kemampuan mengelola modal tetapi tidak memiliki modal tersebut. Semua hal tersebut dapat terpecahkan dalam syarikah yang dibenarkan dalam Islam $^{40}$.

Bergabungnya dua pihak dalam suatu usaha dengan penyertaan modal bersama dalam bentuk keahlian atau kemampuan untuk mengerjakan suatu pekerjaan ini disebut syarikah al-abdan. Dewasa ini, syarikah al-abdan dapat menjadi salah satu solusi bagi para pelaku usaha atau pekerja yang berada dalam taraf ekonomi rendah untuk lebih menyejahterakan kehidupannya. Salah satu contohnya adalah nelayan, dengan menerapkan syarikah al-abdan para nelayan (dua orang nelayan atau lebih) dapat saling bekerja sama dalam mencari ikan tanpa modal hanya sebatas keterampilan serta kemampuannya dalam mencari ikan. Kemudian keuntungan dapat dibagi antara kedua belah pihak disesuaikan dengan pekerjaan yang dilakukan, kemampuan dan pengalaman kerja masing-masing serta menurut kesepakatan bersama di awal.

Islam jelas dalam setiap sektornya, termasuk sektor ekonomi sangat memperhatikan moral dan norma-norma syariat, sehingga apapun yang bertentangan dengan syariat, dan bertentangan juga dengan maqāṣid syar'iyah akan ditolak. Di antara nilai moral dalam ekonomi Islam yaitu; kehalalan, kejujuran, keadilan, menghindari

\footnotetext{
${ }^{39}$ Burhanuddin Susamto, "Pendapat al Mazāhib al Arba'ah Tentang Bentuk Syirkah dan Aplikasinya dalam Perseroan Modern", De Jure, Jurnal Syariat dan Hukum 6, no. 1 (2014) : 17.

${ }^{40}$ Deny Setiawan, "Kerja Sama (Syirkah) Dalam Ekonomi Islam”, Jurnal Ekonomi 21, no. 3 (2013) : 1 .
} 
kezaliman, menghindari kemubaziran dan hal yang tidak bermanfaat, menghindari hal yang haram, bermanfaat bagi orang banyak dan peduli dengan sesama ${ }^{41}$. Setiap pelaku bisnis hendaknya senantiasa menerapkan nilai moral syariat dalam setiap akad muamalah yang dilakukan. Begitu pun dengan nelayan yang akan menerapkan akad syarikah al-abdan dalam mencari ikan, hendaknya memperhatikan dan memenuhi setiap rukun dan syarat dari syarikah al-abdan serta menerapkan nilai-nilai moral syariat dalam pelaksanaan pekerjaan mereka masing-masing. Pengetahuan akan konsep syarikah al-abdan juga sangat diperlukan.

\section{Penerapan Syarikah Al-Abdan pada Profesi Tukang Jahit di Indonesia}

Kondisi tukang jahit di Indonesia, perkembangan usaha dan bisnis di Indonesia semakin berkembang pesat. Para pelaku bisnis dari berbagai sektor saling berlombalomba dalam memunculkan inovasi dan terobosan baru agar dapat tetap bertahan di dalam perekonomian Indonesia. Salah satu peluang bisnis yang cukup menjanjikan dan selalu eksis di setiap perkembangan zaman adalah penjahit. Hal itu dikarenakan tingginya minat dan permintaan masyarakat akan tersedianya busana atau pakaian yang sesuai dengan selera mereka masing-masing. Pakaian merupakan salah satu kebutuhan manusia yang paling mendasar selain pangan dan papan. Dewasa ini pakaian tidak hanya sekedar sebagai penutup badan atau aurat namun juga sebagai salah satu sarana dalam menghias diri.

Penjahit atau tukang jahit merupakan salah satu jenis usaha atau bisnis mikro yang memiliki peluang yang sangat besar. Di mana target pasar penjahit sangat luas, mulai dari anak-anak hingga orang tua. Tidak diragukan lagi salah satu usaha yang tidak begitu mengalami pasang surut dalam dunia bisnis adalah tukang jahit. Namun, dalam pelaksanaan bisnis ini tentu saja akan diperoleh kendala dan hambatan di dalamnya. Tantangan yang biasa diperoleh dalam bisnis tukang jahit yaitu ketidakstabilan harga bahan baku dan biaya produksi. Terutama bagi para tukang jahit rumahan yang umumnya mengerjakan bisnis ini sendirian, sehingga mengakibatkan pengerjaan atau baju atau pesanan cenderung lama dan dapat mengecewakan konsumen ${ }^{42}$. Salah satu solusi dalam mengatasi masalah ini adalah dengan adanya kerja sama dan pendelegasian tugas kepada sesama penjahit.

Sistem ekonomi Islam adalah sistem ekonomi berdasarkan pada ajaran-ajaran dan nilai-nilai yang didasarkan pada Al-Qur'an dan hadis demi mencapai kesejahteraan. Ekonomi Islam adalah suatu ilmu dan aplikasi petunjuk dan aturan syariat yang mencegah ketidakadilan dalam memperoleh dan menggunakan sumber daya material

\footnotetext{
${ }^{41}$ Sofyan Rizal, “Titik Temu dan Sinergi Ekonomi Islam dan Ekonomi Kerakyatan”, Journal of Islamic Economics 3, no. 1. (2011) : 9.

${ }^{42}$ Bang Izal, "Menyiasati Kelemahan Usaha Menjahit", Blog Bang Izal, https://www.bangizaltoy.com/2019/12/kelemahan-usaha-menjahit.html (16 Mei 2020)
} 


\section{BUSTANUL FUQAHA: \\ JURNAL BIDANG HUKUM ISLAM \\ Vol. 2 No. 1 (2021): Hal. 130-147 \\ EISSN: 2723-6021 \\ Website: https://journal.stiba.ac.id}

agar memenuhi kebutuhan manusia agar dapat menjalankan kewajibannya kepada Allah dan masyarakat. Sistem ekonomi Islam mempunyai tujuan sebagai berikut: menciptakan kesejahteraan ekonomi dalam kerangka norma moral Islam, membentuk tatanan sosial yang solid berdasarkan keadilan, persaudaraan yang universal, mencapai distribusi pendapatan dan kekayaan yang adil dan merata, menciptakan kebebasan individu dalam konteks kesejahteraan sosial ${ }^{43}$.

Untuk mewujudkan tujuan tersebut, selain memiliki etika yang baik dalam berekonomi, setiap individu tersebut juga diikat oleh persaudaraan kasih sayang. Sebagai makhluk sosial sudah merupakan kodrat untuk menjalankan konsep kebersamaan dan tolong menolong dalam menghadapi ketidakpastian yang merupakan salah satu prinsip yang sangat mendasar dalam ekonomi Islam. Dengan melakukannya secara bersama (bekerja sama) akan menghasilkan hasil yang lebih maksimal. Salah satu bentuk kerja sama yang disyariatkan di dalam Islam adalah syarikah al-abdan. Adapun pada era kontemporer ini, penerapan syarikah al-abdan dapat ditemukan dalam berbagai macam profesi, seperti; nelayan, tukang bangunan, tukang roti, tukang jahit dan sebagainya.

\section{KESIMPULAN}

Setelah pembahasan ini, maka dapat disimpulkan:

1. Syarikah Al-Abdan adalah kongsi yang dilakukan oleh dua orang atau lebih, masing-masing memiliki pekerjaan, (seperti penjahit, tukang besi, tukang warna pakaian dan lain sebagainya), dan keuntungan dari pekerjaan keduanya dibagi di antara mereka. Hukum syarikah ini, yaitu boleh;

2. Penerapan Syarikah Al-Abdan yang dapat dijumpai pada era kontemporer ini, yaitu profesi nelayan dan tukang jahit, masing-masing dapat bekerja sama dan berkongsi dengan fisiknya, kemudian keuntungan dari kongsi ini akan dibagi kepada mereka berdua.

\section{DAFTAR PUSTAKA}

Al-Qur'an Al-Karim.

Afzalurrahman. Muhammad Sebagai Seorang Pedagang. Jakarta: Yayasan Swarna, 1997.

Al-Dawsirī. Muslim bin Muhammad bin Mājid. al Mumti’ Fà al Qawā'ide al Fiqhiyah. Cet. I; Riyāḍ: Dār Zidn̄̄, 2007.

Al-Fauzān. Șāliḥ Bin Fauzān Bin Abdillāh. al Mulakhkhaṣ al Fiqhī. Riyāẹ : Dār al 'Āṣimah, 1423 H.

${ }^{43}$ Sofyan Rizal, “Titik Temu dan Sinergi Ekonomi Islam dan Ekonomi Kerakyatan”, Journal of Islamic Economics 3, no. 1. (2011). h. 10. 


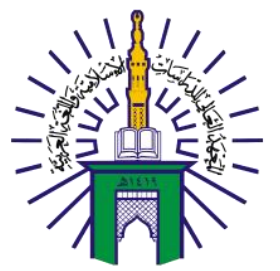

\section{BUSTANUL FUQAHA: \\ JURNAL BIDANG HUKUM ISLAM \\ Vol. 2 No. 1 (2021): Hal. 130-147 \\ EISSN: 2723-6021 \\ Website: https://journal.stiba.ac.id}

Al-Ḥanafî. Abū al Ma'alī Burhanuddin Mahmūd Ibn Aḥmad Ibn Abdil Azīz Ibn Umar Ibn Māzah al Bukhārī. al Muḥ̄t al Burhān̄ì F̄̄ al Fiqhi al Nu'mān̄̄ Fiqh al Imām Abī Hanifah. Cet. I; Beirut: Dār al Kitāb al 'Ilmiyah, 2004.

Al-Ḥanafī. 'Alāuddīn Abū Bakr Ibn Mas'ūd Ibn Aḥmad al Kāsānī. Badāi'u al Ṣanāi' ’̄ F̄̄ Tartīb al Syarāi’i. Cet.II; Dār al Kutub al 'Ilmiyah, 1986.

Al-Ḥanafī. Fakhruddin al Zayla'̄̄. Tabyīn al Haqāiq. Cet. I; Cairo: Al Kubrā al Amīriyah, $1313 \mathrm{H}$.

Al-Jauzī. Jamāluddīn Abū al Faraj Abdurrahman bin Alī bin Muhammad. Manāqib al Imām Ahmad. Cet.II; Dār Hijr, 1409 H.

Al-Madan̄̄. Mālik bin Anas bin Mālik bin 'Āmir al Aṣbahī. Al Mudawwanah. Cet. I; Dār al Kutub al 'Ilmiyah, 1994.

Al-Maqdisī, Abū Muhammad Muwaffaquddin Abdullah Ibn Aḥmad Ibn Muhammad Ibn Qudāmah al Hianbalī. al Mugnī. Maktabah al Qāhirah, 1968.

Al-Nawawī. Abū Zakariyā Muhyiddīn Yahyā bin Syarif. Rawdah al-Ṭālibīn Wa 'Umdah al Muftīn. Cet. III; Beirut: al Maktab al Islāmī, 1991.

Al-Sarakhsī. Muhammad Bin Ahmad Bin Abī Sahli Syamsu al-Aimmah. al Mabsuṭ. Beirut: Dār al-Ma'rifah, 1993.

Al-Sijistānī. Abu Dāwud Sulaiman Bin al-Aysaṣ Bin Ishāq Bin Basȳ̄r Bin Syadād Bin Amri al-Azd̄̄. Sunan Ab̄̄ Dāwud. Cet. I; Dār al-Risālah al-Ālamiyah, 2009.

Al-Qurțubī. Abū al Walīd Muhammad Ibn Aḥmad Ibn Muhammad Ibn Aḥmad Ibn Rusyd. Bidāyah al Mujtahid wa Nihāyah al Muqtașid. Cairo: Dār al Hadīṣ, 2004.

Al-Zuhailī. Wahbah Ibn Musțafā. al-Fiqh al-Islāmīy wa Adillatuhu. Cet. XII; Suriah: Dār al-Fikr, t.th..

Departemen Agama RI. Al-Qur'an Terjemahan. Tangerang Selatan: Kalim, 2011.

Iskandar, Azwar., and Khaerul Aqbar. "Reposisi Praktik Ekonomi Islam: Studi Kritis Praktik Ekonomi Islam di Indonesia." NUKHBATUL'ULUM: Jurnal Bidang Kajian Islam 5, no. 1 (2019) : 39-53.

Izal, Bang "Menyiasati Kelemahan Usaha Menjahit", Blog Bang Izal, https://www.bangizaltoy.com/2019/12/kelemahan-usaha-menjahit.html (16 Mei 2020)

Mardani. Fiqh Ekonomi Syariah : Fiqh Muamalah. Jakarta: Kencana, 2002.

Muhammad. Etika Bisnis Islami. Yogyakarta: Unit Penerbit dan Percetakan Akademi Manajemen Perusahaan YKPN, 2004.

Munawwir. Aḥmad Warson. Kamus al Munawwir Arab-Indonesia. Cet.XIV; Surabaya: Pustaka Progressif, 1997.

Mustaq. Ahmad. Etika Bisnis Dalam Islam. Jakarta : Pustaka al-Kautsar, 2005.

Rizal, Sofyan. "Titik Temu dan Sinergi Ekonomi Islam dan Ekonomi Kerakyatan." Journal of Islamic Economics 3, no. 1 (2011).

Sābiq. Sayyid. Fiqh al-Sunnah. Cet.III; Beirut: Dār al-Kitāb al-Arabi, 1977.

Setiawan. Deny. "Kerja Sama (Syirkah) Dalam Ekonomi Islam." Jurnal Ekonomi 21, no. 3. (2013).

Soemitra. Andri. Hukum Ekonomi Syariah dan Fikih Muāmalah di Lembaga Keuangan dan Bisnis Kontemporer. Cet. I; Jakarta Timur: Prenadamedia Group, 2019. 


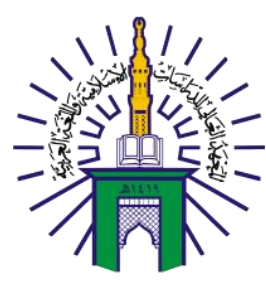

\section{BUSTANUL FUQAHA: \\ JURNAL BIDANG HUKUM ISLAM \\ Vol. 2 No. 1 (2021): Hal. 130-147 \\ EISSN: 2723-6021 \\ Website: https://journal.stiba.ac.id}

Tamboto. Henry J.D. dan Allen A.Ch. Manongko. Model Pengentasan Kemiskinan Masyarakat Pesisir Berbasis Literasi Ekonomi dan Modal Sosial. Cet. I; Malang: CV. Seribu Bintang, 2019.

Tim Ulama Fikih. al-Fiqh al-Muyassar F̄̄ Dau al Kitāb Wa Sunnah. t.t. Mujamma' al Malik Fahd Lițibā'ati al Muṣhaf al Syarīf, 1424 H. 